\title{
New insights into the importance of prolactin in dairy ruminants ${ }^{1}$
}

\author{
P. Lacasse, ${ }^{* 2}$ S. Ollier, ${ }^{*}$ V. Lollivier, $† \ddagger \S$ and M. Boutinaud $\ddagger$ \\ *Dairy and Swine Research and Development Centre, Agriculture and Agri-Food Canada, 2000 College Street, Sherbrooke, Quebec, \\ Canada J1M 0C8 \\ †INRA, UMR1348 PEGASE, F-35590 Saint-Gilles, France \\ †INRA Agrocampus Ouest, UMR1348 PEGASE, F-35000 Rennes, France \\ §Université Européenne de Bretagne, F-35000 Rennes, France
}

\begin{abstract}
In most mammals, prolactin (PRL) is essential for maintaining lactation, and the suppression of PRL inhibits lactation. However, the involvement of PRL in the control of ruminant lactation is less clear, because inconsistent effects on milk yield have been observed with the short-term suppression of PRL by bromocriptine. Therefore, several experiments have been conducted to assess the galactopoietic role of PRL. In an initial experiment, cows in early lactation received daily injections of the dopamine agonist quinagolide for 9 wk. Quinagolide reduced milking-induced PRL release and caused a faster decline in milk production. Quinagolide also reduced mammary epithelial cell activity, survival, and proliferation. In goats, cabergoline, another dopamine agonist, caused a $28 \%$ decrease in milk yield the day after injection. In another experiment, cows were injected for $5 \mathrm{~d}$ with quinagolide, with quinagolide plus bovine PRL injected at milking time, or with vehicles only. Again, quinagolide reduced milk, protein, and lactose yields. Although PRL injections were not sufficient to restore milk yield, they tended to increase milk protein and lactose yields and increased the viability of mammary epithelial cells purified from milk. Recently, our team stimulated PRL secretion with daily injections of the dopamine antagonist domperidone for $5 \mathrm{wk}$. Milk production increased gradually and was greater in domperidone-treated cows during the last $4 \mathrm{wk}$ of the treatment period. In most experiments where PRL secretion was manipulated, feed intake paralleled the changes of PRL concentration, supporting the idea that PRL increases feed intake to provide the nutrients necessary to support lactation in dairy ruminants. In late-lactation cows, quinagolide and cab-
\end{abstract}

\footnotetext{
Received June 30, 2015.

Accepted September 8, 2015.

${ }^{1}$ Presented as part of the Lactation Biology: Mammary Gland Biology Revisited Symposium at the ADSA-ASAS Joint Annual Meeting, Orlando, Florida, July 2015.

${ }^{2}$ Corresponding author: pierre.lacasse@agr.gc.ca
}

ergoline decreased milk production within the first day of treatment and induced more rapid changes in several markers of mammary gland involution after drying-off. In addition, quinagolide improved the resistance to intramammary infection, suggesting that PRL inhibition could be an alternative strategy for facilitating dryingoff. Prolactin appears to directly affect mammary gland functions, but mammary gland responsiveness to PRL appears to be modulated by local and systemic factors. Therefore, the modulation of the number and isoforms of the PRL receptors as well as the expression of intracellular modulators of cell signaling in the mammary gland require further investigation. In conclusion, these data, combined with those from other studies, provide a good body of evidence that PRL is galactopoietic in dairy ruminants.

Key words: lactation, mammary gland, prolactin

\section{INTRODUCTION}

Nearly 90 yr ago, Stricker and Grueter (1929) reported that mammary growth and lactation could be induced in rabbits by injecting aqueous pituitary extracts. Subsequently, Riddle et al. (1933) determined that this effect was due to a hormone produced by the anterior pituitary, which they named prolactin (PRL). The lactotrophs of the anterior pituitary are the predominant source of this hormone, although its mRNA has been detected in the brain and several other tissues (including the mammary gland). Although several hypothalamic substances can act as PRL-releasing factors, the secretion of PRL appears to be regulated primarily by the tuberoinfundibular neurons of the hypothalamus via the inhibitory action of dopamine (Freeman et al., 2000). A large variety of stimuli provided by the environment and the internal milieu can affect PRL secretion. Parturition is associated with a major peak in PRL concentration, and the suppression of PRL prevents lactogenesis (Johke, 1986). Suckling and milking are also powerful inducers of PRL release, but this response decreases as lactation progresses (Selmanoff and Selmanoff, 1983). 
Prolactin is known to be mammogenic and lactogenic in both monogastric and ruminant mammals. Although the role of PRL in monogastric lactation is well recognized, its role in ruminant lactation remains controversial. The purpose of this review is to present older and more recent evidence for a galactopoietic role of PRL in ruminant lactation. This review will also discuss the effect of PRL on DMI to support lactation and how PRL modulation could be used as a management tool. Last, we present evidence that the sensitivity of the mammary gland to PRL is modulated by several factors.

\section{EFFECT OF PROLACTIN ON MILK PRODUCTION IN DAIRY RUMINANTS}

In monogastric mammals, suppression of PRL reduces milk production (Taylor and Peaker, 1975; Flint and Gardner, 1994). However, short-term administration of bromocriptine, a dopamine agonist that suppresses PRL release, to cows and goats, has produced inconsistent effects on milk yield. In a first experiment, Karg et al. (1972) injected 2 cows with increasing daily doses (20 to $160 \mathrm{mg}$ ) of bromocriptine for $3 \mathrm{~d}$ and observed the inhibition of PRL without any effect on milk production. However, in a second experiment, Karg et al. (1972) injected 2 other cows for $7 \mathrm{~d}(5 \mathrm{~d}$ at $150 \mathrm{mg} / \mathrm{d}$ followed by $2 \mathrm{~d}$ at $75 \mathrm{mg} / \mathrm{d}$ ) and reported a 10 to $20 \%$ decline in milk production. Another production assay was performed by Smith et al. (1974), in which 5 cows were treated with $80 \mathrm{mg} / \mathrm{d}$ of bromocriptine for $2 \mathrm{~d}$ without affecting milk production. Hart (1973) injected 3 lactating goats with increasing doses ( 5 to $20 \mathrm{mg} / \mathrm{d}$ ) of bromocriptine with no effect on milk yield, although no statistical analysis was presented. However, a subsequent study reported a $21 \%$ decrease in milk production in 5 goats treated with $0.3 \mathrm{mg} / \mathrm{kg}$ per day bromocriptine for $8 \mathrm{~d}$ (Knight et al., 1990). The inconsistent effects of bromocriptine on milk production seen in earlier experiments are probably attributable to the short-term administration of the inhibitor and the very small number of experimental animals involved.

To assess the effect of the long-term inhibition of PRL release in lactating dairy cows, 8 cows in early lactation received daily injections of quinagolide for $9 \mathrm{wk}$ (Lacasse et al., 2011). Quinagolide is a compound that binds specifically to the dopamine D2 receptor of lactotrophs, decreasing the synthesis and release of PRL (Brownell, 1996). Unlike the ergot alkaloid bromocriptine, which was used in early studies on PRL action in cows, quinagolide has little affinity for serotonin and

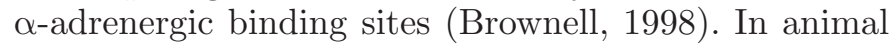
models, quinagolide has a longer half-life, has fewer side effects, and is 200 times more potent than bromocrip- tine in terms of inhibiting rodent lactation (Brownell, 1998). In Lacasse et al. (2011), the dose used (1 mg/d) reduced but did not totally prevent PRL release at milking. In wk 1,4 , and 8 , the amount of PRL released averaged 32,12 , and $20 \%$, respectively, of the amount released before the start of the quinagolide treatment. Milk production declined faster in the quinagolidetreated cows than in the control cows (Figure 1). Milk production was correlated with the amounts (area under the curve) and peak values of milking-induced PRL release, and the coefficients were similar in the control and quinagolide-treated cows. Koprowski and Tucker (1973) also reported that milk production is correlated with milking-induced PRL release, and Akers et al. (1980) observed that milk production is correlated with PRL secretion rate. Therefore, the effect of quinagolide on milk production is most likely mediated by PRL inhibition. In dairy goats $(\mathrm{n}=20)$, quinagolide injections (at a dose of $1 \mathrm{mg} / \mathrm{d}$ ) for 4 wk did not affect milk production but also did not affect either basal or milking-induced release of PRL [B. Ponchon (McGill University, Montreal, Canada), V. Lollivier and M. Boutinaud, unpublished results]. In contrast, a single injection of cabergoline, another dopaminergic inhibitor of PRL secretion, caused a $28 \%$ decrease in milk yield the day after the injection (Figure 2). In contrast to bromocriptine, the newer dopamine agonists quinagolide and cabergoline clearly inhibit milk production in dairy ruminants.

The classical way to demonstrate the action of a hormone is to remove its source, observe the changes induced, and try to restore function by hormone replacement. In lactating goats, hypophysectomy caused

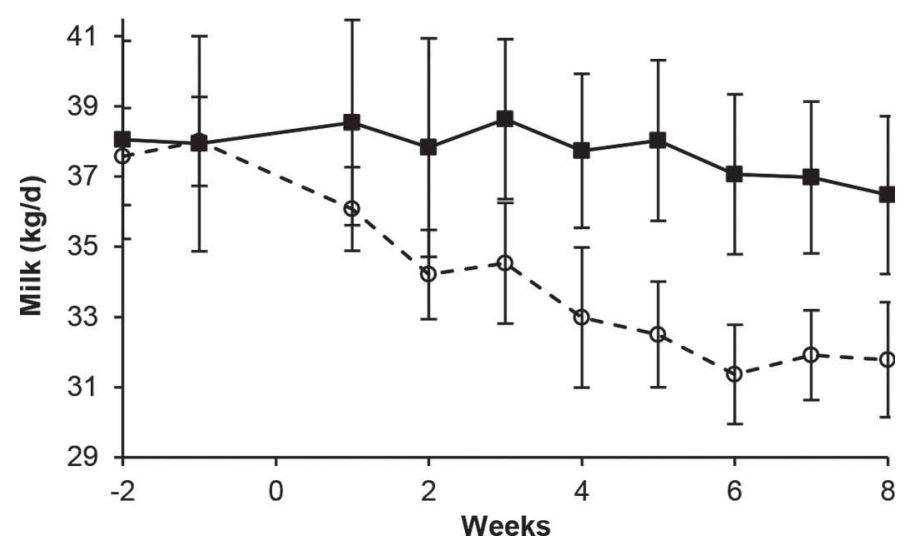

Figure 1. Milk production of dairy cows injected with water ( solid line; $\mathrm{n}=4)$ or quinagolide $(\mathrm{O}$, dashed line; $1 \mathrm{mg} / \mathrm{d} ; \mathrm{n}=5)$ for 8 wk. Quinagolide significantly reduced milk production $(P<0.05)$. Figure adapted from Lacasse et al. (2011) and used with permission. Data are presented as least squares means \pm SEM. 


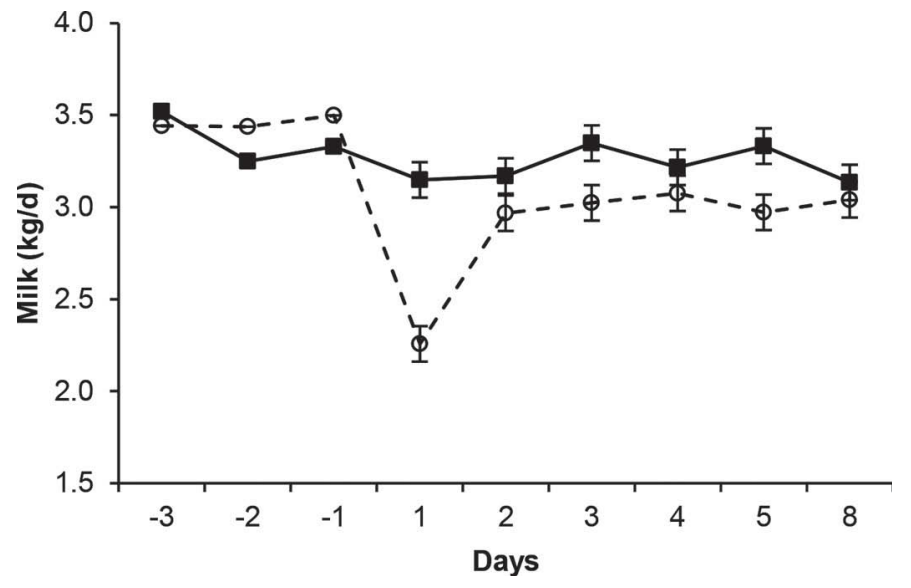

Figure 2. Milk production of dairy goats injected i.m. with $1 \mathrm{mg}$ of cabergoline $(\bigcirc$, dashed line; $\mathrm{n}=5)$ or water (control; $\mathbf{\square}$, solid line; $\mathrm{n}=$ $5)$. The goats were at 60 DIM. Milk production on the day of the injection was lower $(P<0.01)$ in the goats injected with cabergoline $(\mathrm{V}$ Lollivier and M. Boutinaud, unpublished results). Data are presented as least squares means \pm SEM.

a sharp decline in milk production that required PRL and other hormones to be restored (Cowie and Tindal, 1971). In 1 goat, known as "goat 34," once milk production had returned to a normal level, the PRL injections were discontinued with no further decrease in milk production, suggesting that PRL is lactogenic but not galactopoietic in goats (Cowie and Tindal, 1971). However, the situation may not be as straightforward as it seems. The effect of PRL withdrawal was tested in 7 other goats and was found to cause a reduction in milk production (Cowie et al., 1964). Those goats have been forgotten, but goat 34 has not. Goat 34 was given large doses $(12.5 \mathrm{mg} / \mathrm{d})$ of bovine growth hormone (GH), and the removal of that hormone depressed milk production (Cowie and Tindal, 1971). This GH was pituitary-derived, and the contamination of similar preparations with PRL has been reported (Skarda et al., 1982a). In addition, GH and PRL are closely related hormones, and cross-binding activity has been reported when a hormone from one species is used in another species (Gertler et al., 1983). Skarda et al. (1982a) reported that high-purity bovine GH has weak but significant lactogenic activity in goat mammary tissue and that activity may not be eliminated by PRL antibodies. Therefore, the bovine GH used for goat 34 may have contained enough PRL-like activity to maintain lactation, and it was probably premature to conclude that PRL is not galactopoietic in ruminants based on the results for that goat alone. In contrast, Knight (1993) treated 6 goats for $6 \mathrm{~d}$ with bromocriptine $(15 \mathrm{mg} / \mathrm{d})$ with or without ovine PRL at $12 \mathrm{mg} / \mathrm{d}$. Milk production was decreased by $13 \%$ when bromocriptine was injected alone but by only $2 \%$ when PRL was injected with bromocriptine. Recently, Lollivier et al. (2015) conducted an experiment in dairy cows to determine if exogenous PRL is able to counteract the effect of quinagolide on milk production. In that experiment, quinagolide $(1 \mathrm{mg})$ was injected twice a day with or without twice-daily injections of PRL $(2 \mu \mathrm{g} / \mathrm{kg}$ of BW) at milking time for $5 \mathrm{~d}$. As expected, quinagolide prevented milking-induced PRL release and reduced milk production. Although the areas under the curve were similar, the PRL peak for the PRL-injected cows was shorter than that induced by milking for the control cows. The PRL injections were not able to overcome the effect of quinagolide on milk production but tended to increase milk protein yield compared with quinagolide alone. Quinagolide clearly reduced cell activity, given that the expressions of $\alpha$-lactalbumin and $\kappa$-casein genes were depressed in the mammary epithelial cells (MEC) collected from milk. Expressions of these genes in MEC harvested during the quinagolide-plus-PRL treatment were numerically intermediate between the control and quinagolide treatments and not different from either of them. Quinagolide increased the number of MEC harvested from milk, whereas PRL injections tended to decrease it. Prolactin injections also increased the viability of MEC harvested from milk. The percentage of cells positive for proliferating cell nuclear antigen (PCNA) tended to be lower during the quinagolide treatment, but this effect was reversed by PRL injections. Although PRL injections at milking time were not sufficient to restore milk yield to the control level, this experiment provides evidence that the effect of quinagolide is due to the inhibition of PRL release. Nevertheless, we cannot exclude the possibility that part of the effect of quinagolide on milk production is not related to PRL inhibition.

A complete demonstration of the galactopoietic function of PRL requires showing that enhancing the PRL concentration has a positive effect on lactation. Plaut et al. (1987) injected 8 cows in early lactation with recombinant PRL at $120 \mathrm{mg} / \mathrm{d}$ for $14 \mathrm{~d}$ without affecting milk production. Although the injections increased basal plasma PRL 2- to 5-fold, they reduced the milking-induced release of PRL considerably. Conversely, the injection of a much smaller dose of PRL $(1 \mu \mathrm{g} /$ $\mathrm{kg}$ of BW) twice a day for the first 3 wk of lactation tended to increase milk production (Wall et al., 2006). In goats, recombinant PRL injections increased milk yield by over $10 \%$, an increase that was comparable and additive to the increase elicited by GH (Flint and Knight, 1997). In a recent experiment, Lacasse and Ollier (2015) injected mid-lactation cows with domperidone for $5 \mathrm{wk}$. Domperidone is a dopamine antagonist 
that has been shown to induce PRL secretion in several species and to enhance milk production in women (da Silva et al., 2001) and mares (Cross et al., 2012). Domperidone injections caused a gradual increase in basal blood PRL concentration, which was about 3-fold higher than that of the control cows during the last $3 \mathrm{wk}$ of treatment. Milk production was similar for both groups before the treatments started but moderately greater in the domperidone-treated cows during the first $4 \mathrm{wk}$ of treatment (Figure 3). Feed restriction was applied during the last week of treatment, during which time milk production declined in both groups but remained higher in the domperidone-treated cows. The relatively low magnitude of responses in these studies suggests that the ability of the mammary gland to respond to supplemental PRL might be limited. Even in a species where PRL is clearly galactopoietic, such as swine (Farmer et al., 1998), the exogenous injection of PRL failed to increase milk production (Farmer et al., 1999), a result that illustrates the difficulty of demonstrating the galactopoietic effect of PRL by administering exogenous PRL to intact females.

The hypothesis that PRL is galactopoietic in ruminants is also supported by the fact that a long-day photoperiod increases PRL concentration and milk production (Peters et al., 1981; Bilodeau et al., 1989), whereas the administration of melatonin, a neurotrans- mitter produced during the night, for 12 wk decreased PRL and milk production (Auldist et al., 2007). Taken together, the results of all the experiments cited so far in this review provide a strong body of evidence that PRL is galactopoietic in dairy ruminants.

The mechanism by which PRL exerts its galactopoietic role has not been fully explained. Lower levels of CSN3 and LALBA mRNA were detected in mammary biopsies and MEC harvested from cows treated with quinagolide, suggesting that the decrease in milk production appears to be the result of a reduction in cell activity (Boutinaud et al., 2012; Lollivier et al., 2015). Accordingly, PRL injections enhance $L A L B A$ mRNA expression in the mammary gland of dairy cows in early lactation (Wall et al., 2006). In ruminant mammary explants or cultivated MEC, PRL stimulates the synthesis of milk constituents such as caseins and lipids (Skarda et al., 1982b; Goodman et al., 1983; Choi et al., 1988). Nevertheless, cell proliferation was lower and apoptosis was greater in the mammary tissue of quinagolide-treated cows after $8 \mathrm{wk}$ of treatment, results that suggest that cell turnover and involution rate were also affected (Boutinaud et al., 2012). Cell proliferation was enhanced by PRL in cows treated with quinagolide injection (Lollivier et al., 2015). Olazabal et al. (2000) reported that PRL stimulates the proliferation of MEC. Moreover, PRL protects bovine MEC from apoptosis

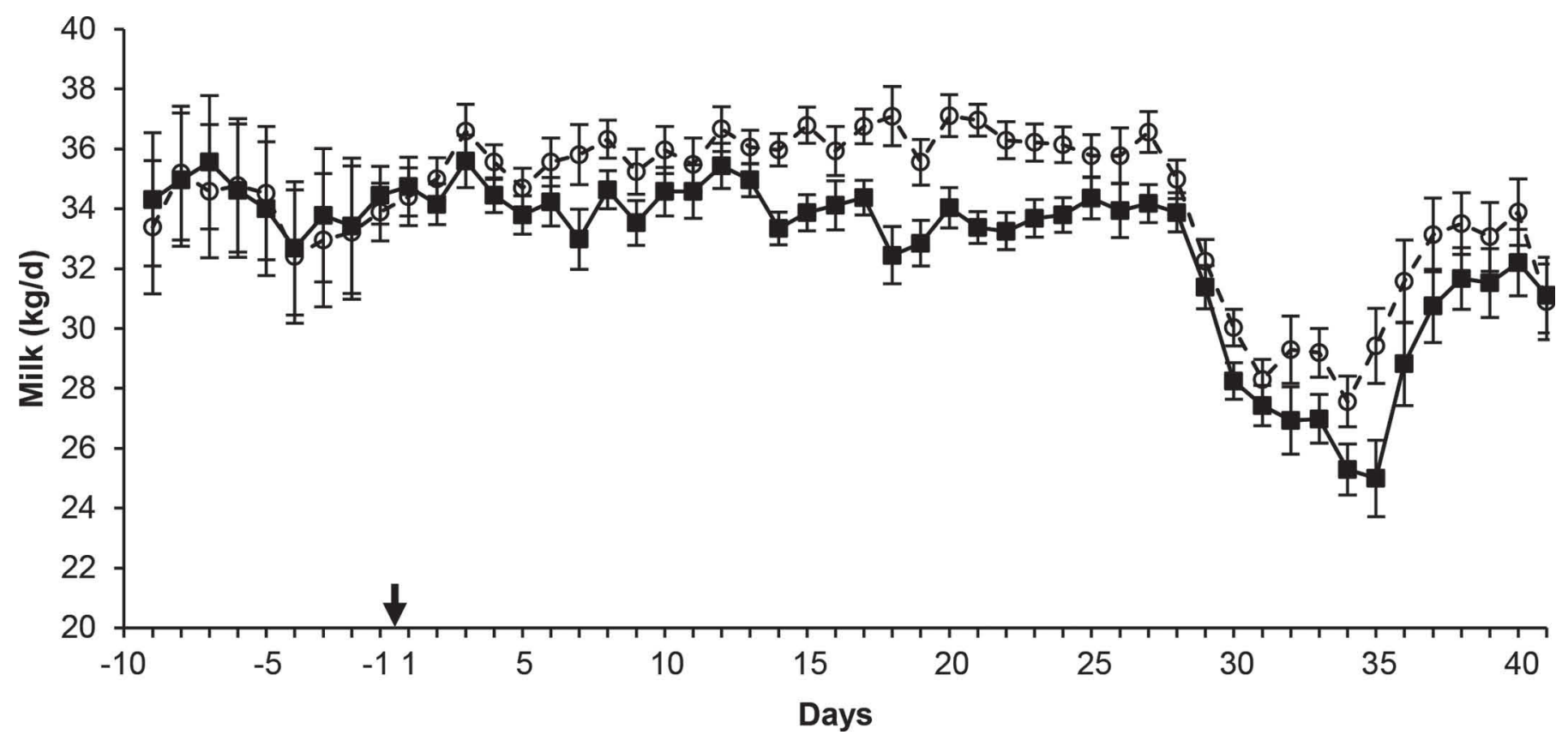

Figure 3. Milk production of dairy cows injected daily s.c. with $300 \mathrm{mg}$ of domperidone $(\bigcirc$, dashed line; $\mathrm{n}=9)$ or canola oil $($ control; solid line; $\mathrm{n}=9$ ) for $34 \mathrm{~d}$. The cows were feed-restricted ( $65 \%$ of the previous week's DMI) from d 29 to 35 . The start of injections is indicated by an arrow. Milk production was greater $(P<0.01)$ in the cows injected with domperidone (Lacasse and Ollier, 2015; used with permission). Data are presented as least squares means \pm SEM. 
by suppressing the expression of an inhibitor of IGF action, IGF-binding protein 5 (IGFBP-5; Accorsi et al., 2002). Accordingly, PRL injections in cows treated with quinagolide injection significantly downregulated the $B A X$ mRNA level in mammary tissue (Lollivier et al., 2015). Thus, it appears that PRL plays a galactopoietic role in the ruminant mammary gland by maintaining the number of MEC in the gland and their differentiated state.

\section{EFFECT OF PROLACTIN ON FEED INTAKE IN DAIRY RUMINANTS}

Feed intake increases moderately in late gestation and markedly during lactation to support the demand for fetal development and milk production. Given that the increases in blood PRL and placental lactogen (which can bind to PRL receptors) during pregnancy and lactation parallel the increase in feed intake, they are logical candidates for mediating these effects. In rats, PRL injections increased feed intake (Byatt et al., 1993; Sauvé and Woodside, 1996). In most studies where PRL secretion of cows was inhibited by injecting quinagolide, feed intake was reduced (Lacasse et al., 2011; Ollier et al., 2013, 2014, 2015). Accordingly, domperidone injections increased DMI slightly (Lacasse and Ollier, 2015). Although these changes could have occurred in response to the changes in milk production, the injection of nonlactating female rats with PRL was also found to increase feed intake (Byatt et al., 1993; Sauvé and Woodside, 1996). Similarly, our team observed a trend toward lower DMI in dry cows treated with quinagolide (P. Lacasse and S. Ollier, unpublished results). In rodents, the suckling stimulus activates neuropeptide $Y$ neurons in the dorsomedial nucleus of the hypothalamus, an effect that was found to be reduced by bromocriptine and restored by ovine PRL ( $\mathrm{Li}$ et al., 1999; Chen and Smith, 2004). In addition, PRL was found to increase neuropeptide $\mathrm{Y}$ transcription in vitro (Arumugam et al., 2007). Neuropeptide $\mathrm{Y}$ is a potent appetite-stimulating neurotransmitter in several species, including sheep (Sartin et al., 2010), and it is thought to play an important role in the increase in feed intake in early lactation of dairy cows (Ingvartsen and Andersen, 2000). Although further investigations are required, these results support the proposition of Arumugam et al. (2007) that PRL increases feed intake to provide the nutrients necessary to support lactation.

\section{PROLACTIN INHIBITION AS A MANAGEMENT TOOL}

Drying-off is a challenging period for high-yielding cows, because they are often dried off while still producing significant quantities of milk (Dingwell et al.,
2001) and, consequently, are highly susceptible to new IMI (Rajala-Schultz et al., 2005). The mammary gland becomes much more resistant to infection when active involution is completed. Therefore, strategies that reduce milk production before drying-off or accelerate mammary gland involution or both would be important management tools.

In this context, PRL inhibition could be used to reduce milk production at drying-off and accelerate the rate of mammary involution after cessation of milking. In a first experiment, Ollier et al. (2013) injected late-lactation cows twice daily with quinagolide $(2 \mathrm{mg}$ per injection) or water from $4 \mathrm{~d}$ before drying-off until $3 \mathrm{~d}$ after. Quinagolide reduced the basal serum PRL concentration before and after drying-off as well as the PRL released in blood during milking. The PRL inhibitor induced a $20 \%$ decrease in milk production before drying-off. The increases in somatic cells and BSA in milk during early involution were greater in the quinagolide-treated cows, suggesting that involution was hastened. Similarly, a single injection of $5.6 \mathrm{mg}$ of cabergoline just after the last milking before dryingoff enhanced extracellular matrix remodeling in the mammary gland, MEC exfoliation into milk, and the migration of somatic cells into mammary secretions in dairy cows (Boutinaud et al., 2013a). Moreover, the changes observed in lactose content, lactoferrin content, lactoferrin-to-citrate ratio, and fat content in mammary secretions and in GLUT-1 mRNA and lactoferrin staining in the mammary tissue indicated that cabergoline treatment hastened mammary gland involution (Boutinaud et al., 2013b, 2015). In another experiment, Ollier et al. (2014) compared the effects of the PRLinhibition strategy with those of a drastic reduction in feed supply in the days that precede drying-off, a method commonly used to reduce milk production. Cows received dry hay during the last $5 \mathrm{~d}$ before drying-off or twice-daily i.m. injections of $4 \mathrm{mg}$ of quinagolide from $5 \mathrm{~d}$ before drying-off until $13 \mathrm{~d}$ after. A control group was neither feed-restricted nor treated with quinagolide. Both procedures decreased milk production at dryingoff and hastened mammary gland involution. However, feed restriction decreased blood concentrations of glucose and most AA and increased blood concentrations of BHB and nonesterified fatty acids (NEFA), whereas quinagolide had little effect on these metabolites. Previous studies have shown that high blood NEFA levels have a negative effect on peripheral blood mononuclear cell functions (Carbonneau et al., 2012; Ster et al., 2012); accordingly, serum harvested on the drying-off day from hay-fed cows reduced the proliferation and IL-4 production of these cells. Another group of cows received the same treatments but were challenged by daily teat dipping in a solution containing Streptococ- 
cus agalactiae at $5 \times 10^{7} \mathrm{cfu} / \mathrm{mL}$ during the first $7 \mathrm{~d}$ of the dry period (Ollier et al., 2015). Again, feeding with dry hay and quinagolide injection induced a major decrease in milk production (Figure 4A). However, only the PRL-inhibition strategy reduced the incidence of new IMI at drying-off (Figure 4B). These experiments show that the inhibition of PRL release induces a sharp decrease in the milk production of cows in late lactation, accelerates mammary gland involution, and reduces susceptibility to IMI in a $S$. agalactiae challenge. Taken together, these results indicate that this strategy could be an alternative tool for facilitating drying-off, especially in high-yielding cows.

As stated in the previous section, quinagolide treatment at drying-off also induced a decrease in feed intake. Therefore, the effect of quinagolide on milk production might be related to this effect. Nevertheless, the comparison of the effects of quinagolide to the feed restriction caused by hay feeding clearly shows that it is not the case. Indeed, the magnitude of the effect on feed intake is much lower than that on milk production. The effect of quinagolide on milk production is already maximal after the first injection, whereas the effect on feed intake takes several days. When cows are fed only dry hay, which results in an even greater decrease in nutrient intake, milk production decreases gradually, with concomitant decreases in blood glucose and several AA and increased blood BHB and NEFA levels. Finally, it is important to note that metabolite analyses provided no evidence that cows treated with quinagolide were in negative energy balance.

During the periparturient period, the abrupt increase in energy demand for milk production often leads to metabolic disorders. Previous experiments showed that reducing milk output by milking once a day or partially in the first days of lactation reduces metabolic disturbances (Loiselle et al., 2009; Carbonneau et al., 2012). Therefore, Vanacker et al. (2015) carried out an experiment to determine if inhibition of PRL could be used to limit milk production during the first week of lactation and thus reduce metabolic stress. A total of 22 cows were injected twice daily for the first $4 \mathrm{~d}$ of lactation with either water (control) or $2 \mathrm{mg}$ of quinagolide. Quinagolide reduced milk production during the first week of lactation but had no residual effect on milk production in the following weeks. Blood glucose and calcium concentrations were greater and BHB concentration was lower in the quinagolide-treated cows than in the control cows during the first week of lactation. These early results suggest that reducing the PRL peak at calving is effective in reducing metabolic stress during the first week of lactation without compromising the overall productivity of the dairy cow.

\section{IS THE RESPONSE TO PROLACTIN MODULATED AT THE LEVEL OF THE MAMMARY GLAND?}

In some situations, it appears that the responsiveness of the mammary gland to the PRL galactopoietic signal is modulated by local or systemic factors. In Lacasse et al. (2011), in the last week of quinagolide treatment, cows were milked differentially: one udder half was milked twice daily, whereas the other half was milked once daily. During that week, the inhibitory effects of quinagolide on milk, milk protein, and milk fat yields were maintained in the udder half that was milked twice daily but lost in the half milked once daily (Figure 5). Reciprocally, a unilateral increase in milking frequency increased the milk response to PRL administration in goats (Knight, 1993). McKinnon et al. (1988) observed that increasing the milking frequency increased the PRL-binding capacity of the mammary gland. Accordingly, in cows milked differentially (1 udder half milked once daily and the other milked 3 times daily), the gene expression of long and short isoforms of PRL receptors was higher in the glands milked more frequently (Bernier-Dodier et al., 2010; Thompson et al., 2015). Therefore, it is possible that milk removal (or lack thereof) affects the responsiveness of the mammary gland to PRL.

The circulating level of PRL might also affect mammary gland responsiveness to PRL. A short-day photoperiod during the dry period was found to reduce circulating PRL during the dry period and increase subsequent milk production (Auchtung et al., 2005; Lacasse et al., 2014). In Lacasse et al. (2014), milk production in the first $20 \mathrm{wk}$ of lactation was enhanced by about $10 \%$ by previous exposure to a short-day photoperiod during the dry period. However, the effect decreased as lactation advanced, such that no stimulation was observed during the second $20 \mathrm{wk}$ of lactation. The fact that the milk response gradually decreased during lactation is more compatible with a galactopoietic response that occurs during lactation than with a mammogenic response that occurs during the dry period. An effect on mammary gland development would likely last for the whole lactation and not wane in a few weeks. Several pieces of evidence suggest that the reduction in the PRL concentration during the dry period is a determining factor for the dry-period photoperiod effect. Auchtung et al. (2005) reported that the mammary glands of cows exposed to a shortday photoperiod during the dry period had a higher expression of PRL receptors than did the mammary glands of cows exposed to a long-day photoperiod. This difference was observed for both the long and short receptor isoforms and persisted throughout the dry pe- 
riod and during the first days of lactation. Shortening the dry period was shown to shorten the period of lower PRL concentration that precedes calving and to lead to a decrease in milk production in the following lactation (Bernier-Dodier et al., 2011). Heat stress increases PRL concentration, and cooling during the dry period is fol-
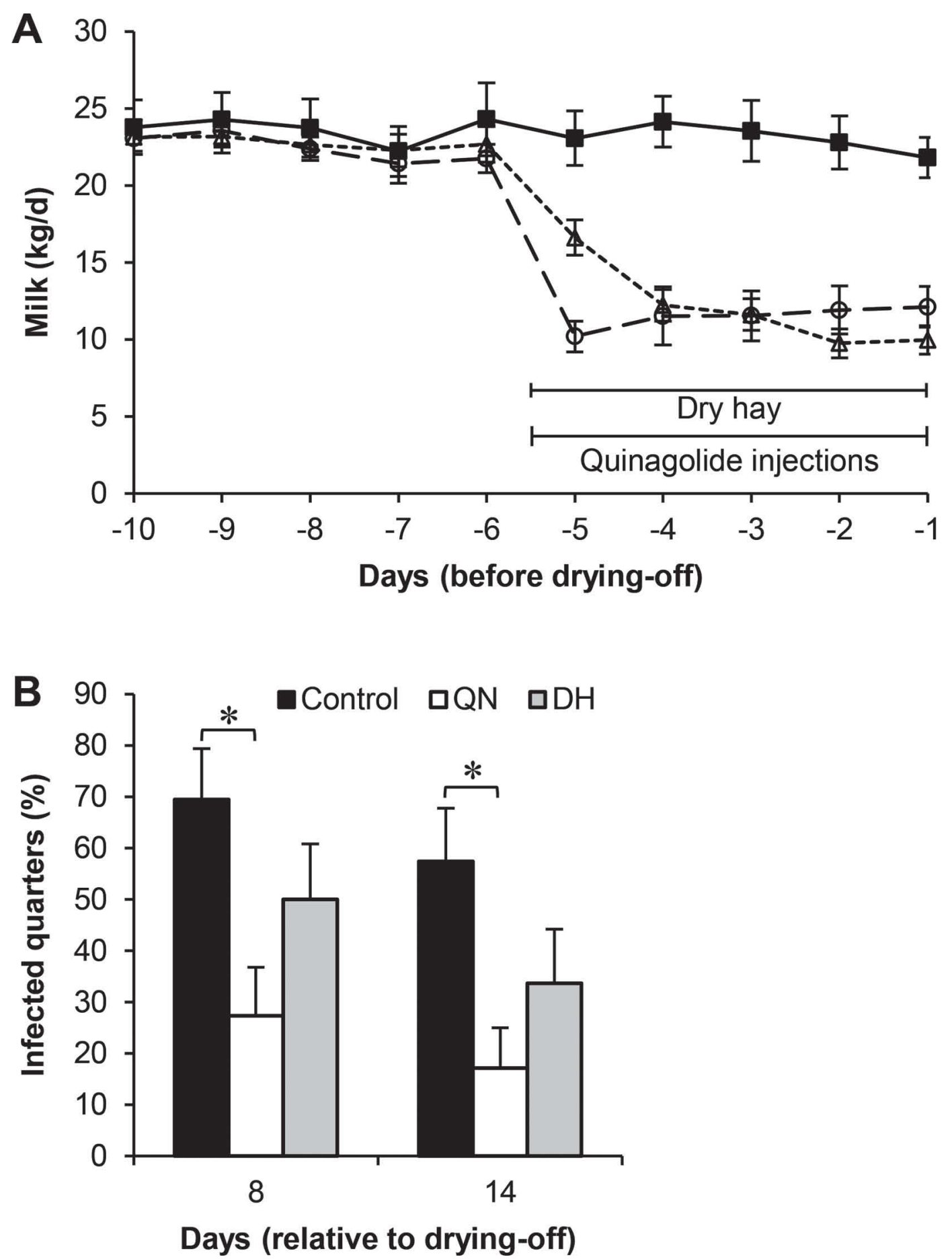

Figure 4. Milk production during the last $10 \mathrm{~d}$ of lactation (A) and infection rate in mammary secretions (B) of cows injected twice daily with $4 \mathrm{mg}$ of quinagolide from $5 \mathrm{~d}$ before drying-off until $13 \mathrm{~d}$ after $(\mathrm{O}$, long dashed line; QN), cows fed only dry hay for the last $5 \mathrm{~d}$ before drying-off $(\Delta$, short dashed line; DH), and control cows ( $\mathbf{\square}$, solid line). All teats of each cow were dipped daily, from d 1 to 7 after the last milking, in a solution containing Streptococcus agalactiae at $5 \times 10^{7} \mathrm{cfu} / \mathrm{mL}$. A quarter was reported as infected when the mammary secretion sample contained $S$. agalactiae at $\geq 20 \mathrm{cfu} / \mathrm{mL}$. Data are presented as least squares means $\pm \mathrm{SEM} ; * P<0.05$. Adapted from Ollier et al. (2015) and used with permission. 


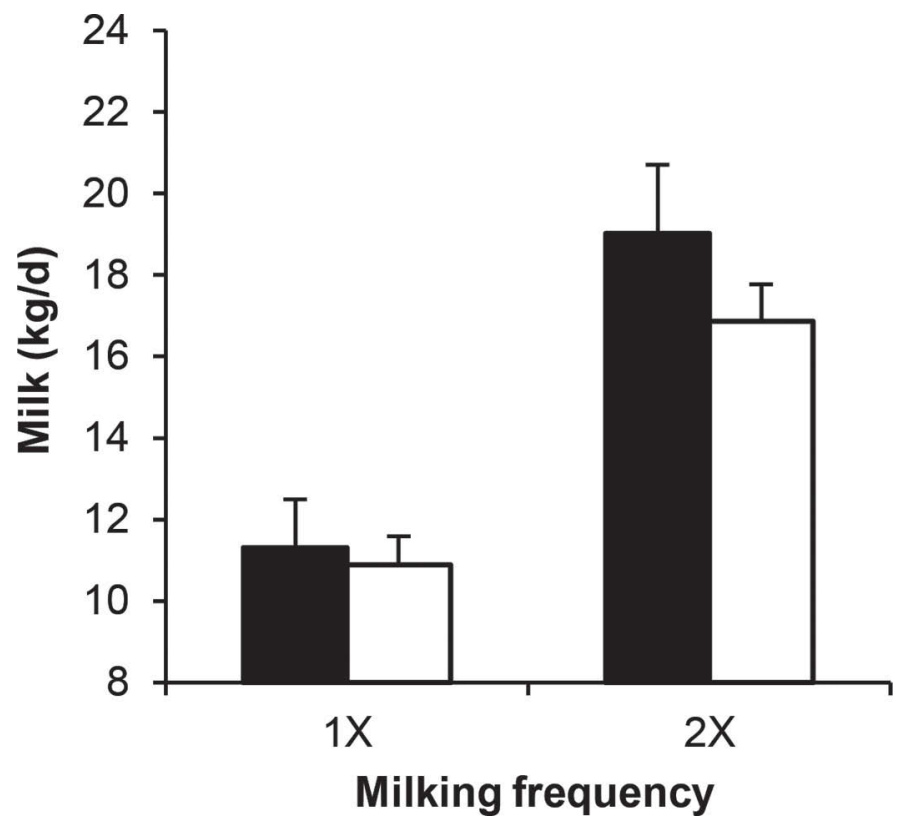

Figure 5. Effect of injecting water (black bars) or quinagolide (white bars; $1 \mathrm{mg} / \mathrm{d}$ ) and of differential milking [1 udder half milked once a day $(1 \times)$ and the other half milked twice a day $(2 \times)]$ on the milk production of dairy cows. The inhibitory effect of quinagolide persisted in the udder half that was milked $2 \times(P=0.03)$ but disappeared in the half milked $1 \times$. Figure adapted from Lacasse et al. (2011) and used with permission. Data are presented as least squares means \pm SEM.

lowed by enhanced milk production (Tao and Dahl, 2013). Accordingly, the infusion of recombinant PRL into cows exposed to a short-day photoperiod during the dry period reduced the milk response (Crawford et al., 2005). In the previously cited studies on drying-off management, PRL was inhibited during the early dry period (Ollier et al., 2013, 2014, 2015). Even though those experiments were not designed to determine the effect of these treatments on milk production in the following lactation, an increase in production was observed in animals that had received the inhibitor (Figure 6), a result that supports the concept that PRL can influence responsiveness to its own signal.

During established lactation, blood and milk PRL concentrations are generally similar, and factors that affect blood concentration also affect milk concentration. Intramammary infusion of colchicine reduces the transfer of PRL from blood into milk (Akers and Kaplan, 1989), which suggests that PRL is transferred across the alveolar epithelium rather than between secretory cells. It has been shown that PRL is internalized via endocytosis in mammary cells, transported through Golgi stacks, and released into milk via secretory vesicles containing casein micelles (Ollivier-Bousquet, 1998). In goats, the transfer of ${ }^{125}$ I-labeled PRL into milk was reduced when endogenous PRL was high or when unlabeled PRL was infused, and it was enhanced by bromocriptine-induced hypoprolactinemia (Forsyth et al., 1995), a finding that indicates the presence of a competitive and saturable mechanism of transfer. The infusion of domperidone (Lacasse and Ollier, 2015) also increased milk PRL concentration; however, the efficiency of transfer of PRL from blood into milk was much lower in those cows. Malven (1983) presented evidence that the milk transfer of PRL plays a role in lactogenesis and postulated that this transfer could also

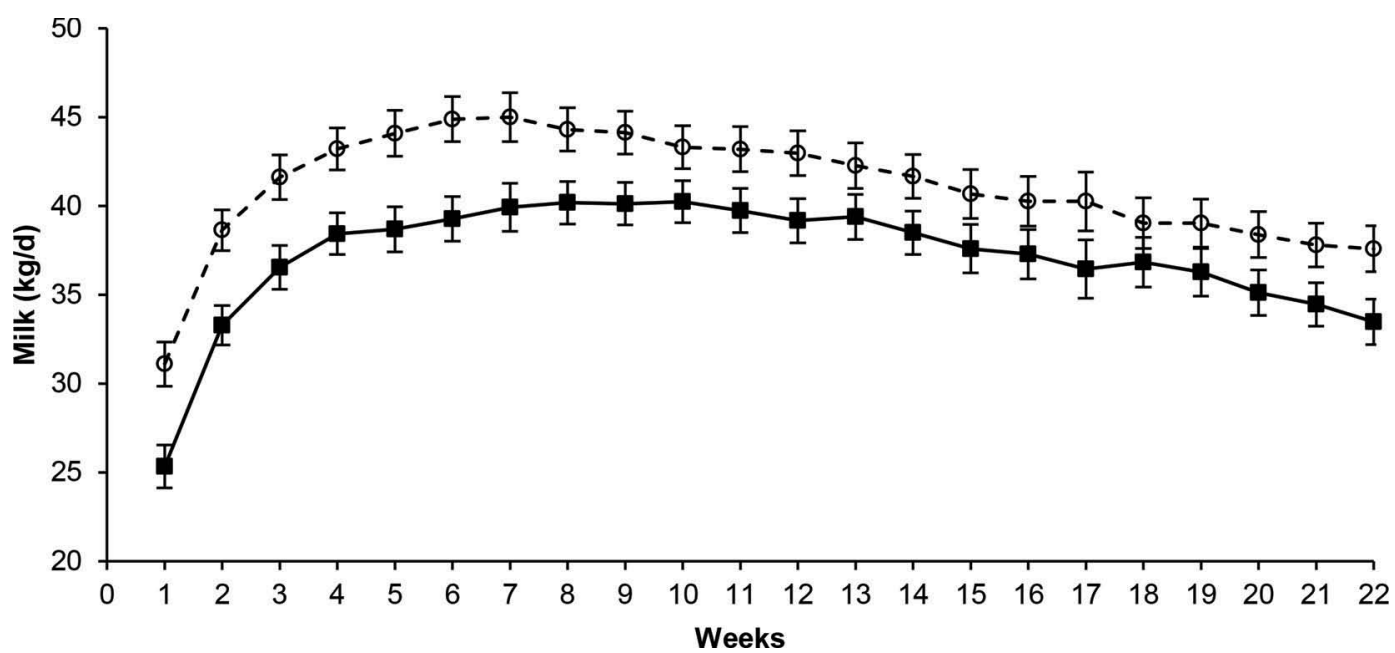

Figure 6. Milk production during the following lactation of cows injected twice daily with quinagolide (- - --$)$ or water $(-\mathbf{\square}-)$ before drying-off and during the early dry period (see Ollier et al., 2013, 2014, 2015, for more details). Milk production was greater $(P=0.02)$ in the quinagolide-treated cows (S. Ollier and P. Lacasse, unpublished results). Data are presented as least squares means \pm SEM. 
be involved in galactopoiesis. If that is the case, the milk transfer of PRL may contribute to the resistance of ruminant lactation to PRL manipulation.

\section{CONCLUSIONS}

The results of several experiments now support the hypothesis that PRL is galactopoietic in dairy cows and goats. In addition to milk production, PRL appears to also affect DMI and is probably involved in increased feed intake during lactation to provide the nutrients necessary to support milk synthesis. Prolactin appears to affect mammary gland functions directly, but the response to PRL appears to be modulated by local and systemic factors. Therefore, the modulation of the number and the isoforms of the PRL receptors as well as the expression of intracellular modulators of cell signaling in the mammary gland require further investigation. Our results suggest that PRL inhibition could be used as a management tool to facilitate drying-off and to reduce metabolic stress during the transition period for high-producing dairy cows.

\section{ACKNOWLEDGMENTS}

The authors thank the teams at the Dairy and Swine Research and Development Centre (Sherbrooke, QC, Canada) and at the UMR1348 PEGASE (Rennes, France) for taking care of the cows, helping with the blood sampling, and providing technical assistance. The authors are grateful to Mary Varcoe, from the Translation Bureau, Public Works and Government Services Canada, for her careful editing of this manuscript. This research was financially supported by Agriculture and Agri-Food Canada, the Dairy Farmers of Canada (Ottawa, ON, Canada), the Institut National de la Recherche Agronomique (INRA, France), the Action Concerté Novalait-MAPAQ-FQRNT-AAFC (Quebec City, QC, Canada), the Canadian Bovine Mastitis Research Network (Montreal, QC, Canada), and the Natural Sciences and Engineering Research Council of Canada (Ottawa, ON, Canada).

\section{REFERENCES}

Accorsi, P. A., B. Pacioni, C. Pezzi, M. Forni, D. J. Flint, and E. Seren. 2002. Role of prolactin, growth hormone and insulin-like growth factor 1 in mammary gland involution in the dairy cow. J. Dairy Sci. 85:507-513.

Akers, R. M., G. T. Goodman, and H. A. Tucker. 1980. Clearance and secretion rates of prolactin in dairy cattle in various physiological states. Proc. Soc. Exp. Biol. Med. 164:115-119.

Akers, R. M., and R. M. Kaplan. 1989. Role of milk secretion in transport of prolactin from blood into milk. Horm. Metab. Res. 21:362-365.
Arumugam, R., D. Fleenor, and M. Freemark. 2007. Lactogenic and somatogenic hormones regulate the expression of neuropeptide $\mathrm{Y}$ and cocaine- and amphetamine-regulated transcript in rat insulinoma (INS-1) cells: interactions with glucose and glucocorticoids. Endocrinology 148:258-267.

Auchtung, T. L., A. G. Rius, P. E. Kendall, T. B. McFadden, and G. E. Dahl. 2005. Effects of photoperiod during the dry period on prolactin, prolactin receptor, and milk production of dairy cows. J. Dairy Sci. 88:121-127.

Auldist, M. J., S. A. Turner, C. D. McMahon, and C. G. Prosser. 2007. Effects of melatonin on the yield and composition of milk from grazing dairy cows in New Zealand. J. Dairy Res. 74:52-57.

Bernier-Dodier, P., L. Delbecchi, G. F. Wagner, B. G. Talbot, and P. Lacasse. 2010. Effect of milking frequency on lactation persistency and mammary gland remodeling in mid-lactation cows. J. Dairy Sci. 93:555-564.

Bernier-Dodier, P., C. L. Girard, B. G. Talbot, and P. Lacasse. 2011. Effect of dry period management on mammary gland function and its endocrine regulation in dairy cows. J. Dairy Sci. 94:4922-4936.

Bilodeau, P. P., D. Petitclerc, N. St Pierre, G. Pelletier, and G. J. St Laurent. 1989. Effects of photoperiod and pair-feeding on lactation of cows fed corn or barley grain in total mixed rations. J. Dairy Sci. 72:2999-3005.

Boutinaud, M., N. Isaka, A. Deflandre, E. Gandemer, P.-G. Marnet, F. Dessauge, and V. Lollivier. 2013a. Prolactin-inhibitor cabergoline enhanced the mammary remodeling during drying-off in dairy cows. J. Dairy Sci. 96(E-Suppl. 2):151. (Abstr.)

Boutinaud, M., N. Isaka, A. Deflandre, E. Gandemer, P.-G. Marnet, F. Dessauge, and V. Lollivier. 2013b. Prolactin-inhibitor cabergoline hastened the mammary involution during the drying-off in dairy cows. J. Dairy Sci. 96(E-Suppl. 2):324. (Abstr.)

Boutinaud, M., N. Isaka, A. Deflandre, S. Wiart, P. Lamberton, L. A. De Prado Taranilla, and V. Lollivier. 2015. Dry-off facilitator cabergoline hastened the GLUT-1 decrease and lactoferrin increase in the mammary tissue during drying-off in dairy cows. J. Dairy Sci. 98(E-Suppl. 2):406. (Abstr.)

Boutinaud, M., V. Lollivier, L. Finot, R. M. Bruckmaier, and P. Lacasse. 2012. Mammary cell activity and turnover in dairy cows treated with the prolactin-release inhibitor quinagolide and milked once daily. J. Dairy Sci. 95:177-187.

Brownell, J. 1996. Quinagolide (Norprolac): A novel non-ergot prolactin inhibitor. Drugs Today (Barc) 32:1-31.

Brownell, J. 1998. Quinagolide in hyperprolactinaemia. Rev. Contemp. Pharmacotherap. 9:1-75.

Byatt, J. C., N. R. Staten, W. J. Salsgiver, J. G. Kostelc, and R. J Collier. 1993. Stimulation of food intake and weight gain in mature female rats by bovine prolactin and bovine growth hormone. Am. J. Physiol. 264:E986-E992.

Carbonneau, E., A. M. de Passillé, J. Rushen, B. G. Talbot, and P. Lacasse. 2012. The effect of incomplete milking or nursing on milk production, blood metabolites, and immune functions of dairy cows. J. Dairy Sci. 95:6503-6512.

Chen, P., and M. S. Smith. 2004. Regulation of hypothalamic neuropeptide Y messenger ribonucleic acid expression during lactation: role of prolactin. Endocrinology 145:823-829.

Choi, Y. J., W. L. Keller, I. E. Berg, C. S. Park, and A. G. Mackinlay. 1988. Casein gene expression in bovine mammary gland. J. Dairy Sci. 71:2898-2903.

Cowie, A. T., G. S. Knaggs, and J. S. Tindal. 1964. Complete restoration of lactation in the goat after hypophysectomy. J. Endocrinol. $28: 267-279$.

Cowie, A. T., and J. S. Tindal. 1971. The physiology of lactation. Williams and Wilkins Co., Baltimore, MD.

Crawford, H. M., J. L. Dauderman, D. E. Morin, T. B. McFadden, and G. E. Dahl. 2005. Evidence of a role of prolactin in mediating photoperiodic effects during the dry period. J. Dairy Sci. 88(ESuppl. 1):363. (Abstr.)

Cross, D. L., C. R. Reinemeyer, J. C. Prado, R. L. Donnell, K. G. Bond, H. Farr, and S. L. Longhofer. 2012. Efficacy of domperidone 
gel in an induced model of fescue toxicosis in periparturient mares. Theriogenology 78:1361-1370.

da Silva, O. P., D. C. Knoppert, M. M. Angelini, and P. A. Forret. 2001. Effect of domperidone on milk production in mothers of premature newborns: A randomized, double-blind, placebo-controlled trial. CMAJ 164:17-21.

Dingwell, R. T., D. F. Kelton, K. E. Leslie, and V. L. Edge. 2001. Deciding to dry-off: Does level of production matter? Pages 69-79 in Proc. National Mastitis Council Annual Meeting, Arlington, VA. National Mastitis Counc., Madison, WI.

Farmer, C., S. Robert, and J. Rushen. 1998. Bromocriptine given orally to periparturient or lactating sows inhibits milk production. J. Anim. Sci. 76:750-757.

Farmer, C., M. T. Sorensen, S. Robert, and D. Petitclerc. 1999. Administering exogenous porcine prolactin to lactating sows: Milk yield, mammary gland composition, and endocrine and behavioral responses. J. Anim. Sci. 77:1851-1859.

Flint, D. J., and M. Gardner. 1994. Evidence that growth hormone stimulates milk synthesis by direct action on the mammary gland and that prolactin exerts effects on milk secretion by maintenance of mammary deoxyribonucleic acid content and tight junction status. Endocrinology 135:1119-1124.

Flint, D. J., and C. H. Knight. 1997. Interactions of prolactin and growth hormone $(\mathrm{GH})$ in the regulation of mammary gland function and epithelial cell survival. J. Mammary Gland Biol. Neoplasia 2:41-48.

Forsyth, I. A., J. A. Taylor, G. Gabai, and I. R. Fleet. 1995. Blood prolactin concentrations affect prolactin transfer into goat milk: implications for maintenance of lactation. J. Endocrinol. 146:411420.

Freeman, M. E., B. Kanyicska, A. Lerant, and G. Nagy. 2000. Prolactin: Structure, function, and regulation of secretion. Physiol. Rev. 80:1523-1631.

Gertler, A., N. Cohen, and A. Maoz. 1983. Human growth hormone but not ovine or bovine growth hormones exhibits galactopoietic prolactin-like activity in organ culture from bovine lactating mammary gland. Mol. Cell. Endocrinol. 33:169-182.

Goodman, G. T., R. M. Akers, H. Friderici, and H. A. Tucker. 1983. Hormonal regulation of alpha-lactalbumin secretion from bovine mammary tissue cultured in vitro. Endocrinology 112:1324-1330.

Hart, I. C. 1973. Effect of 2-bromo-Q-ergocryptine on milk yield and the level of prolactin and growth hormone in the blood of the goat at milking. J. Endocrinol. 57:179-180.

Ingvartsen, K. L., and J. B. Andersen. 2000. Integration of metabolism and intake regulation: A review focusing on periparturient animals. J. Dairy Sci. 83:1573-1597.

Johke, T. 1986. Prolactin secretion and lactogenesis in dairy cows and goats. Vlaams Diergen. Tijds. 55:251-257.

Karg, H., D. Schams, and V. Reinhardt. 1972. Effects of 2-Br- ergocryptine on plasma prolactin level and milk yield in cows. Experientia 28:574-576.

Knight, C. H. 1993. Prolactin revisited. Pages $72-80$ in Yearbook. Hannah Research Institute, Ayr, UK

Knight, C. H., D. Foran, and C. J. Wilde. 1990. Interaction between autocrine and endocrine control of milk yield: Thrice-daily milking and bromocriptine-treated goats. J. Reprod. Fertil. Abstr. Ser. $5: 20$.

Koprowski, J. A., and H. A. Tucker. 1973. Serum prolactin during various physiological states and its relationship to milk production in the bovine. Endocrinology 92:1480-1487.

Lacasse, P., V. Lollivier, R. M. Bruckmaier, Y. R. Boisclair, G. F. Wagner, and M. Boutinaud. 2011. Effect of the prolactin-release inhibitor quinagolide on lactating dairy cows. J. Dairy Sci. 94:1302-1309.

Lacasse, P., and S. Ollier. 2015. The dopamine antagonist domperidone increases prolactin concentration and enhances milk production in dairy cows. J. Dairy Sci. 98:7856-7864.

Lacasse, P., C. M. Vinet, and D. Petitclerc. 2014. Effect of prepartum photoperiod and melatonin feeding on milk production and prolactin concentration in dairy heifers and cows. J. Dairy Sci 97:3589-3598.

Li, C., P. Chen, and M. S. Smith. 1999. Neuropeptide Y and tuberoinfundibular dopamine activities are altered during lactation: role of prolactin. Endocrinology 140:118-123.

Loiselle, M. C., C. Ster, B. G. Talbot, X. Zhao, G. F. Wagner, Y. R. Boisclair, and P. Lacasse. 2009. Impact of postpartum milking frequency on the immune system and the blood metabolite concentration of dairy cows. J. Dairy Sci. 92:1900-1912.

Lollivier, V., P. Lacasse, J. Angulo Arizala, P. Lamberton, S. Wiart, J. Portangen, R. M. Bruckmaier, and M. Boutinaud. 2015. In vivo inhibition followed by exogenous supplementation demonstrates galactopoietic effects of prolactin on mammary tissue and milk production in dairy cows. J. Dairy Sci. 98:8775-8787. http:// dx.doi.org/10.3168/jds.2015-9853.

Malven, P. V. 1983. Transfer of prolactin from plasma into milk and associated physiological benefits to mammary cells. Endocrinol. Exp. 17:283-299.

McKinnon, J., C. Knight, D. Flint, and C. Wilde. 1988. Effect of milking frequency and efficiency on goat mammary prolactin receptor number. J. Endocrinol. 119(Suppl. 3):116. (Abstr.)

Olazabal, I., J. Muñoz, S. Ogueta, E. Obregón, and J. P. García-Ruiz. 2000. Prolactin (PRL)-PRL receptor system increases cell proliferation involving JNK (c-Jun amino terminal kinase) and AP-1 activation: Inhibition by glucocorticoids. Mol. Endocrinol. 14:564-575.

Ollier, S., X. Zhao, and P. Lacasse. 2013. Effect of prolactin-release inhibition on milk production and mammary gland involution at drying-off in cows. J. Dairy Sci. 96:335-343.

Ollier, S. X. Zhao, and P. Lacasse. 2014. Effects of feed restriction and prolactin-release inhibition at drying off on metabolism and mammary gland involution in cows. J. Dairy Sci. 97:4942-4954.

Ollier, S., X. Zhao, and P. Lacasse. 2015. Effects of feed restriction and prolactin-release inhibition at drying-off on susceptibility to new intramammary infection in cows. J. Dairy Sci. 98:221-228.

Ollivier-Bousquet, M. 1998. Transferrin and prolactin transcytosis in the lactating mammary epithelial cell. J. Mammary Gland Biol. Neoplasia 3:303-313.

Peters, R. R., L. T. Chapin, R. S. Emery, and H. A. Tucker. 1981. Milk yield, feed intake, prolactin, growth hormone, and glucocorticoid response of cows to supplemented light. J. Dairy Sci. 64:1671-1678.

Plaut, K., D. E. Bauman, N. Agergaard, and R. M. Akers. 1987. Effect of exogenous prolactin administration on lactational performance of dairy cows. Domest. Anim. Endocrinol. 4:279-290.

Rajala-Schultz, P. J., J. S. Hogan, and K. L. Smith. 2005. Short communication: Association between milk yield at dry-off and probability of intramammary infections at calving. J. Dairy Sci. $88: 577-579$.

Riddle, O., R. W. Bates, and S. W. Dykshorn. 1933. The preparation, identification and assay of prolactin - a hormone of the anterior pituitary. Am. J. Physiol. 105:191-216.

Sartin, J. L., J. A. Daniel, B. K. Whitlock, and R. R. Wilborn. 2010. Selected hormonal and neurotransmitter mechanisms regulating feed intake in sheep. Animal 4:1781-1789.

Sauvé, D., and B. Woodside. 1996. The effect of central administration of prolactin on food intake in virgin female rats is dose-dependent, occurs in the absence of ovarian hormones and the latency to onset varies with feeding regimen. Brain Res. 729:75-81.

Selmanoff, M., and C. Selmanoff. 1983. Role of pup age, estradiol-17 beta and pituitary responsiveness in the differences in the sucklinginduced prolactin response during early and late lactation. Biol. Reprod. 29:400-411.

Skarda, J., E. Urbanova, S. Becka, L. M. Houdebine, C. Delouis, D. Pichova, J. Picha, and J. Bilek. 1982a. Effect of bovine growth hormone on development of goat mammary tissue in organ culture. Endocrinol. Exp. 16:19-31.

Skarda, J., E. Urbanova, and J. Bilek. 1982b. Effect of progesterone, triiodothyronine and metabolic inhibitors on prolactin stimulated lipid synthesis in goat mammary explants. Endocrinol. Exp. $16: 81-92$ 
Smith, V. G., T. W. Beck, E. M. Convey, and H. A. Tucker. 1974. Bovine serum prolactin, growth hormone, cortisol and milk yield after ergocryptine. Neuroendocrinology 15:172-181.

Ster, C., M. C. Loiselle, and P. Lacasse. 2012. Effect of postcalving serum nonesterified fatty acids concentration on the functionality of bovine immune cells. J. Dairy Sci. 95:708-717.

Stricker, P., and F. Grueter. 1929. Recherches experimentales sur les fonctions du lobe anterieur de l'hypophyse: influence des extraits du lobe anterieur sur l'appareil genital de la lapine et sur la montee laiteuse. Presse Med. 37:1268-1271.

Tao, S., and G. E. Dahl. 2013. Invited review: Heat stress effects during late gestation on dry cows and their calves. J. Dairy Sci. 96:4079-4093

Taylor, J. C., and M. Peaker. 1975. Effects of bromocriptine on milk secretion in the rabbit. J. Endocrinol. 67:313-314.
Thompson, I. M., S. Ollier, X. Zhao, and P. Lacasse. 2015. Effects of milking frequency and domperidone on milk production and expression of prolactin receptors in the mammary gland of dairy cows. J. Dairy Sci. 98(E-Suppl. 2):407. (Abstr.)

Vanacker, N., S. Ollier, R. Blouin, and P. Lacasse. 2015. The effect of inhibiting the lactogenic signal at calving on milk production and metabolic perturbations in cows. J. Dairy Sci. 98(E-Suppl. 2):408. (Abstr.)

Wall, E. H., H. M. Crawford, S. E. Ellis, G. E. Dahl, and T. B. McFadden. 2006. Mammary response to exogenous prolactin or frequent milking during early lactation in dairy cows. J. Dairy Sci. 89:4640-4648. 